\title{
Cost Efficiency, Market Power, Solvency Risk, and Capital Adequacy for Listed Banks in Egypt
}

\author{
Aly Saad Mohamed Dawood \\ Department of Business Administration, Faculty of Management, Sadat Academy for Management Sciences, Cairo, Egypt, Seconded to \\ Faculty of Business \& Economics, Heliopolis University for Sustainable Development, Cairo, Egypt \\ Email address: \\ Ali.saad@hu.edu.eg

\section{To cite this article:} \\ Aly Saad Mohamed Dawood. Cost Efficiency, Market Power, Solvency Risk, and Capital Adequacy for Listed Banks in Egypt. Journal of \\ Finance and Accounting. Vol. 8, No. 3, 2020, pp. 107-114. doi: 10.11648/j.jfa.20200803.11
}

Received: March 26, 2020; Accepted: April 26, 2020; Published: May 14, 2020

\begin{abstract}
This research aims to investigate the stability of Egyptian banks' performance by measuring causal interrelation measurements between efficiency, market power, banks risk-taking, and capital adequacy variables, which might help decisionmakers in banking system to direct their efforts in handling them. The data are collected from Egyptian Information Dissemination for the period from 2013 to 2017 for both income statement and balance sheet. These data are utilized to estimate cost efficiency, market power and calculate the banks risk-taking by using Front 4.1 package and multi-regressions have been applied to measure the causal interrelation between the above-mentioned variables. The results show that Union National Bank Egypt and Export Development Bank have the highest cost efficiency. And, Union National Bank Egypt and Egyptian Gulf Bank have the highest market power, while Suez Canal Bank and Qatar National Bank Alahly have the lowest market power. But low standard deviation range show that there is no significant effort for enhancing neither cost efficiency nor market power. The regression analysis of causal interrelation shows that capital adequacy ratio significantly responds positively to market power and negatively to cost efficiency, as such risk-taking significantly responds positively to both cost efficiency and market power, while both capital adequacy ratio and risk-taking are not responding significantly to each other. And, cost efficiency significantly responds negatively to capital adequacy and positively to both market power and bank risk-taking, moreover market power significantly responds positively to capital adequacy and negatively to both cost efficiency and bank risk-taking. Most results are consistent with literature review except capital adequacy ratio and risk- taking is not responding significantly to each other this may be addressed by some of activated acts of law 88 year 2003 that limit risk-taking for many risk types.
\end{abstract}

Keywords: Banks Costs Efficiency, Banks Market Power, Banks Risk-taking, Banks Capital Adequacy

\section{Introduction}

Over the past decade, the Egyptian banking system has faced several global and local threats. These threats have included the global financial crisis in 2008, the 25th Egyptian revolution in 2011, the high volatility of Egyptian stock Exchange indexes, as well as the floatation of the Egyptian Pound in November 2016 which resulted in a steep devaluation of the currency, high inflation rates, and high interest rate volatility. All of these threats have contributed to weaken the overall stability of the banking sector in Egypt. However, despite these threats and challenges, the preliminary survey for both the bank sector index and its profitability for the last ten years showed the following:

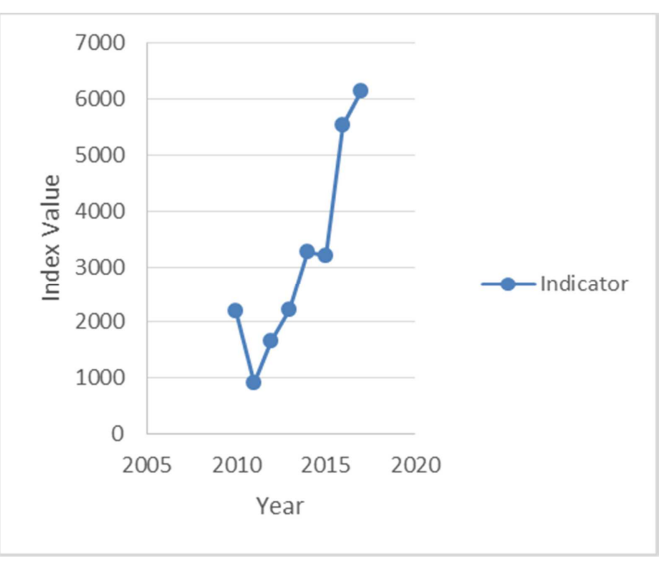

Figure 1. Egyptian Stock Exchange (EGX) Banks sector index. 
Figure 1 shows the rising trend of the banks sector stocks index which reflect the strength and stability of the sector. In the face of economic and political risks taken place within the period from 2010 to 2017 , the index rose from 2,204 points in 2010 to 6,144 points in 2017 demonstrating an overall increase of $179 \%$.

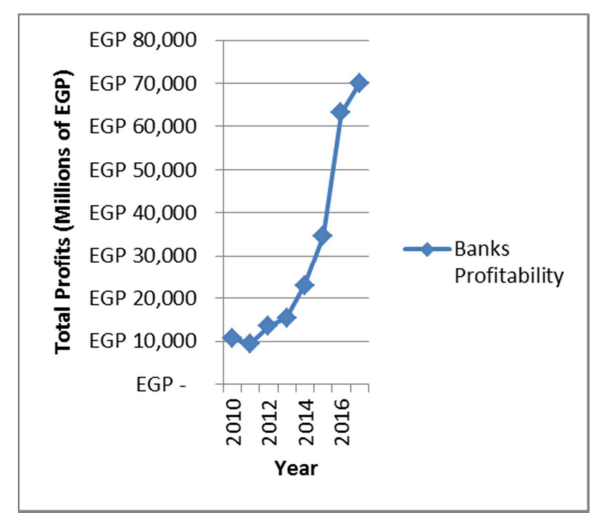

Figure 2. Egyptian Banks' Profitability.

While the profitability of Egyptian banks rose from EGP 3.3 billion in 2004 to EGP 70.2 billion in 2017 billion EGP thus increasing by $2,027.3 \%$.

This phenomenon raises questions about the extent of efficiency, market power, banks risk-taking, capital adequacy and many other variables that might lead to such stability.

So, the causal interrelation measurements between those variables have become more important to investigate, which might help decision makers in banking system to direct their efforts in handling costs, risk-taking, maintaining bank competitive position and determining the level of capital adequacy.

The rest of the paper will be organized as follows. Section 2 explores the literature review, section 3 details the data collection and methodology, section 4 presents the results and its analysis, and section 5 extracts the conclusion and recommendations.

\section{Literature Review}

\subsection{On Capital Adequacy}

The study [1] showed a significant positive relation between cost efficiency and capital adequacy. While the study [2] test the impact of risk-taking behavior, competition and cost efficiency on bank profitability and his study identified that both high competition and insolvency risk significantly influenced the profitability of Chinese commercial banks. Furthermore, the study [3] found that the positive impact of cost efficiency on profitability is stronger when banks undertake higher levels of risk and face more competition. Also, [4], found a significant negative relation between risk (z-score) and capital adequacy. And, the study [5] showed that concentration leads to lower the levels of default, market risks, and asset risks, it exacerbated the levels of capital and liquidity risks. In addition, the study [6] examined the behavior of banking risk in emerging economies, and found that higher systemic risk encourages banks to increase their capital ratio. Besides this, the study [7] examined the interplay between risk, capital and efficiency of Indian banks and found that the more efficient institutions among public sector hold more capital.

\subsection{On Cost Efficiency}

The study [8] compared the cost efficiency of banks in ten south east European countries and revealed a statistically significant cost efficiency gap between EU and non-EU banking systems in the region, where advanced banking systems tend to be more cost efficient than their emergent counterpart. Furthermore, the study [9] found that increasing income diversification tends to improve bank efficiency. While, the study [10] provided estimates of bank efficiency and productivity and his results demonstrated a strong links of competition and concentration with bank efficiency. Also, the study [11] showed that the intense market competition compels Chinese commercial banks to develop advanced technical experience and skills, thus improving their technical efficiency. And, the study [12] showed that an increase in market power (less competition) leads to greater bank cost efficiency. And, the study [13] aimed to measure banking efficiency by considering risk preferences by adopting a method which allows for endogenous classification of three risk preferences, namely the conservative, moderate, and aggressive risk modes by changing direction vectors, findings showed that the moderate risk preference was the most appropriate strategy to achieve technical efficiency in the Chinese banking sector.

\subsection{On Market Power}

The study [14] assessed the market power pre and post crisis periods and found that there was bank level market power appears to vary significantly with respect to ownership characteristics, asset quality and capitalization which have different effects on the margins in the pre-crisis and crisis periods. And, the study [15] evaluated the effectiveness of China's financial reforms by utilizing foreign banks performance as a benchmark which characterized by intense competition and found that domestic banks had gradually caught up the cost advantage with the increased competitive pressure. Also, the study [16] test causality from cost efficiency to bank growth and then from bank growth to market concentration and results showed that growth leads to higher market concentration/bank market power due to cost efficiency.

\subsection{On Risks}

The study [17] studied the real effects of bank competition and found that, on average, bank market power wasn't for mitigating the negative real effects of a systemic banking crisis. While, the study [18] investigated the role of governance in limiting excessive risk-taking at times of turmoil and results showed that banks with good governance push for less risky positions, especially during the financial crisis period relative to the pre-crisis boom. And, the study [19] investigated whether Central and Eastern European 
banks require greater market power to be safer and results suggested that more market power reduces the fragility of banking institutions. Furthermore, the study [4] tried to identify the effect of induced capital regulatory pressure on both banks foregone value and risk-taking and results showed that higher capital requirements pressure brings a lower foregone value for banks, which in turn increases their risktaking. Also, the study [20] examined the effect of higher capital ratios on risk level and improving the efficiency and profitability of banking institutions and findings suggested rising capital ratio may have a negative effect on the efficiency and profitability of highly liquid banks. And, the study [3] tested the joint impact of different types of risk, competition in different banking markets and different types of efficiency on bank profitability using a sample of Chinese commercial banks and found that the positive impact of cost efficiency on profitability is stronger when banks undertake higher levels of risk and face more competition.

The literature review showed the following aspects:

1. Higher capital levels tend to have positive effect on efficiency levels and negative effect to risk (z-score).

2. Developed countries banks are more efficient than banks from developing countries.

3. Cost efficiency management enables banks to grow and increase their market share.

4. Capital adequacy effect is overpowering pushing for more risky positions.

5. Intense market competition tends to increase technical efficiency and consequently had positive association with risk-taking.

6. Bank market power wasn't on average useful for mitigating the negative real effect of a systematic banking crisis.
Most of the previous studies tried to estimate capital adequacy, risks, efficiency, and market power as dependent variables from different perspectives. While, this research main contribution is to examine the causal interrelation between capital adequacy, cost efficiency, market power and insolvency risk. In doing so, the following question will be addressed:

What is the degree of causal interrelation among capital adequacy, cost efficiency, market power and insolvency risk?

How we can use the results to achieve better financial performance in the sampled banks?

\section{Data and Methodology}

Mono-method has been utilized where the researcher used data of banks' balance sheets and income statements for the period from 2013 to 2017, and applied on two steps the first include the estimation of cost efficiency by following the study [2] market power, risk-taking by using Lerner index, and zscore respectively. This was executed by utilizing Front 4.1 applying Stochastic Frontier Analysis; which is conventional econometric technique build to estimate cost or productivity or profit function parameters using regression techniques where deviations of observed choices from optimal ones are modeled as statistical noise. Second, multi-regression has been utilized on E-Views9 to measure the inter-causal of cost efficiency, market power, risk-taking and capital adequacy; research; variables can be defined as follows:

Research variables

Lncost: Estimation of cost efficiency

Following [2] cost efficiency measures the distance of a specific bank to the benchmark bank with regard to the difference in the ability to minimize cost in producing the same volume of output. The model is expressed in equation (1):

$$
\begin{gathered}
\text { LNCOSTit }=\alpha_{0}+\alpha_{1} \text { LNASSET }_{i t}+\frac{1}{2} \alpha_{2}(\text { LNASSETit })^{2}+\sum_{i=1}^{3} \text { BitjLNINPUT itj } \\
+\sum_{j=1}^{3} \sum_{k=1}^{3} \text { BitjkINPUTitjININPUTitk }+\sum_{j=1}^{3} \text { yitjLNASSETSitININPUTitk }+ \text { Vit }+\mu i t
\end{gathered}
$$

Where:

$i$ and $t$ represent a specific bank at a specific year

LNCOST stands for total cost (Interest expenses + noninterest expenses)

LN denotes natural Algorithm

Asset stands for total assets on output which is total assets

INPUT represents three input prices: price of funds (ratio of interest expenses to total funding), price of capital (the ratio of non-interest expense to fixed assets), and price of labor

Vit is a two-sided normal disturbance term with zero mean and variance $\sigma^{2}$ which represents the effect of statistical noise

$\mu$ it is a non-negative random disturbance term capturing the effects of inefficiency

LNLerner_Index: Market Power

Following the study [2, 19], and [21], the model for market power is as follows in equation (2):

$$
\text { LNLerner index }=\frac{P_{i t}-M C_{i t}}{P_{i t}}
$$

Where $\mathrm{MC}_{\mathrm{it}}$ represents marginal costs, which is calculated as follows in equation (3):

$$
\begin{gathered}
M C_{i t}=\frac{\text { Cost }_{i t}}{\text { Assets }_{i t}}\left(\alpha_{1}+\alpha_{2} \text { LNASSETS Assests }_{i t}+\right. \\
\left.\sum_{j=1}^{3} \text { LNINPUT }_{i t j}\right)
\end{gathered}
$$

Which represents the price which in calculated as the total revenue divided by total assets.

Where:

LCAPITAL_ADQUACY: Capital adequacy ratio

LCAPITAL_ADQUACY: Capital adequacy ratio

Following (Bitar et al., 2018) capital adequacy ratio is equal total equity to total assets ratio.

LZSCORE: insolvency risk

Following the study [2, 22], and [23] and others utilized a $\mathrm{Z}$-score which reflect the extent banks have the ability to absorb the losses. Thus, higher value of Z-score indicates lower risk and greatest stability. The Z-score is represented in 
equation (4).

$$
Z=\frac{R O A+{ }^{E} / A}{\sigma_{R O A}}
$$

Where
ROA is banks returns on assets

$\mathrm{E} / \mathrm{A}$ is the ratio of equity to total assets

$\sigma_{\mathrm{ROA}}$ is the standard deviation of ROA.

Furthermore, four models have been applied as follows:

$$
\begin{gathered}
\text { LCAPITAL.ADEQUACY }=\beta_{0}+\beta_{1}+\beta_{2} L L E R N E R . I N D E X+\beta_{3} L Z S C O R E+\varepsilon \ldots \\
\text { LNCOST }=\beta_{0}+\beta_{1} L C A P I T A L . A D E Q U A C Y+\beta_{2} L L E R N E R . I N D E X+\beta_{3} L Z S C O R E+\varepsilon \ldots \\
\text { LLERNER.INDEX }=\beta_{0}+\beta_{1} L C A P I T A L . A D E Q U A C Y+\beta_{2} L N C O S T+\beta_{3} L Z S C O R E+\varepsilon \ldots \\
\text { LZSCORE }=\beta_{0}+\beta_{1} L C A P I T A L . A D E Q U A C Y+\beta_{2} L L N C O S T+\beta_{3} L E R N E R . I N D E X+\varepsilon \ldots
\end{gathered}
$$

Where:

Capital adequacy $=$ the ratio of equity to total assets.

LNCOST represents the output in appendix Table 1 of measuring cost efficiency model in (1).

LLERNER_INDEX represents the output in appendix Table 1 of measuring market power model in (2).

LZSCORE represents the output in appendix Table 1 of formula in (3).

\section{Results}

Table 1 show that Union National Bank Egypt and
Export Development Bank have the highest cost efficiency with scores of 0.832 and 0.818 respectively. While, Societe Arabe International De Banque and National Bank of Kuwait Egypt have the lowest cost efficiency with scores of 0.671 and 0.696 respectively. Moreover, Societe Arabe International De Banque and Qatar National Bank Alahly are the most stable cost efficiency with the lowest standard deviations of 0.043 and 0.051 respectively. This

\begin{tabular}{|c|c|c|c|c|}
\hline \multicolumn{5}{|l|}{ Cost Efficiency } \\
\hline Bank Name & Mean & Standard Deviation & Minimum & Maximum \\
\hline Societe Arabe International De Banque & 0.671 & 0.043 & 0.604 & 0.716 \\
\hline National Bank of Kuwait Egypt & 0.696 & 0.056 & 0.606 & 0.743 \\
\hline Credit Agricole Egypt & 0.736 & 0.155 & 0.602 & 0.962 \\
\hline Egyptian Gulf Bank & 0.751 & 0.136 & 0.600 & 0.962 \\
\hline HSBC bank & 0.755 & 0.078 & 0.652 & 0.82 \\
\hline Suez Canal Bank & 0.755 & 0.077 & 0.655 & 0.842 \\
\hline Al Baraka Bank Egypt & 0.784 & 0.067 & 0.717 & 0.874 \\
\hline Housing and Development Bank & 0.786 & 0.084 & 0.693 & 0.874 \\
\hline Commercial International Bank & 0.787 & 0.076 & 0.689 & 0.875 \\
\hline Abu Dhabi Islamic Bank & 0.798 & 0.126 & 0.656 & 0.962 \\
\hline Qatar National Bank Alahly & 0.807 & 0.051 & 0.719 & 0.848 \\
\hline Export Development Bank & 0.818 & 0.108 & 0.69 & 0.963 \\
\hline Union National Bank Egypt & 0.832 & 0.100 & 0.691 & 0.962 \\
\hline
\end{tabular}
reflects that these banks didn't take significant actions to enhance their cost efficiency during the 2013 - 2017 periods.

Table 1. Cost Efficiency Scores of Egyptian Banks.

Table 2 shows that that Union National Bank Egypt and Egyptian Gulf Bank have the highest market power with mean scores of 0.908 and 0.874 respectively, while Suez Canal Bank and Qatar National Bank Alahly have the lowest market power with scores 0.262 and 0.338 respectively. As such, Egyptian Gulf Bank and National Bank of Kuwait Egypt are the most stable with the lowest standard deviation values of 0.030 and 0.036 respectively, which reflects that these banks didn't take significant actions to enhance their competitive position during the period 2013-2017.

Table 2. Market Power of Egyptian Banks.

\begin{tabular}{llll}
\hline Bank Name & Mean & Standard Deviation & Minimum \\
\hline Union National Bank Egypt & 0.908 & 0.036 & 0.85 \\
Egyptian Gulf Bank & 0.874 & 0.03 & 0.83 \\
National Bank of Kuwait Egypt & 0.806 & 0.036 & 0.77 \\
Credit Agricole Egypt & 0.728 & 0.056 & 0.9 \\
Housing and Development Bank & 0.698 & 0.07 & 0.86 \\
Faisal Islamic Bank & 0.68 & 0.075 & 0.63 \\
Export Development Bank & 0.648 & 0.227 & 0.63 \\
HSBC bank & 0.602 & 0.111 & 0.39 \\
Al Baraka Bank Egypt & 0.504 & 0.184 & 0.48 \\
Abu Dhabi Islamic Bank & 0.438 & 0.091 & 0.95 \\
\hline
\end{tabular}




\begin{tabular}{lllll}
\hline Bank Name & Mean & Standard Deviation & Minimum & Maximum \\
\hline Societe Arabe International De Banque & 0.418 & 0.058 & 0.33 & 0.48 \\
Commercial International Bank & 0.414 & 0.076 & 0.35 & 0.54 \\
Qatar National Bank Alahly & 0.338 & 0.35 & 0.10 & 0.94 \\
Suez Canal Bank & 0.262 & 0.141 & 0.11 & 0.40 \\
\hline
\end{tabular}

Table 3 shows that market power has strong positive impact while, cost efficiency has a negative one on capital adequacy ratio where $\mathrm{R} 2=92.8 \%$ with acceptable correlation of independent variables according to multicollinearity test, and this may reflect that weakness of competition and high cost efficiency which lead to more capital adequacy in Egypt. This is consistent with most of literature researches such as the study [4, 5], and [20]. While risk-taking had a nonsignificant effect, which contradicted with most of the results of the literature, this addresses some of activated acts included within Law No. 88 of the Year 2003 that reduced the level of many types of bank-risk-taking beside banks policies in granting loans and intense investments in governmental securities.

Table 3. The impact of cost efficiency, market power and risk-taking on capital adequacy.

\begin{tabular}{|c|c|c|c|c|}
\hline \multicolumn{5}{|c|}{$\begin{array}{l}\text { Dependent Variable: LCAPITAL_ADEQUACY } \\
\text { Method: Panel Least Squares } \\
\text { Date: } 08 / 20 / 19 \text { Time: } 15: 35 \\
\text { Sample: } 15 \\
\text { Periods included: } 5 \\
\text { Cross-sections included: } 14 \\
\text { Total panel (balanced) observations: } 70\end{array}$} \\
\hline Variable & Coefficient & Std. Error & t-Statistic & Prob. \\
\hline LLERNER_INDEX & -0.560577 & 0.055101 & -10.17356 & 0.0000 \\
\hline LCOST & -196.0967 & 13.37015 & -14.66675 & 0.0000 \\
\hline LZSCORE & $\begin{array}{l}0.177617 \\
\text { Effects Spec }\end{array}$ & 0.150555 & 1.179748 & 0.2434 \\
\hline \multicolumn{5}{|c|}{ Cross-section fixed (dummy variables) } \\
\hline R-squared & 0.939677 & \multicolumn{2}{|c|}{ Mean dependent var } & 14.47052 \\
\hline Adjusted R-squared & 0.921467 & \multicolumn{2}{|c|}{ S. D. dependent var } & 0.163188 \\
\hline Sum squared resid & 0.110843 & \multicolumn{2}{|c|}{ Schwarz criterion } & -2.578481 \\
\hline Log likelihood & 126.3590 & \multicolumn{2}{|c|}{ Hannan-Quinn criter. } & -2.907641 \\
\hline F-statistic & 51.60047 & \multirow{2}{*}{\multicolumn{2}{|c|}{ Durbin-Watson stat }} & 3.484577 \\
\hline Prob (F-statistic) & 0.000000 & & & \\
\hline
\end{tabular}

Table 4 shows that market power (less competition) and bank risk-taking have positive effect, while capital adequacy ratio has negative effect on cost efficiency that $\mathrm{R} 2=97.2 \%$ with acceptable correlation of independent variables according to multicollinearity test. These results consistent with most of literature researches such as the study $[1,12]$ and [24] and many others.

Table 4. The impact of market power, capital adequacy and risk-taking on cost efficiency.

\begin{tabular}{|c|c|c|c|c|}
\hline \multicolumn{5}{|l|}{$\begin{array}{l}\text { Dependent Variable: LCOST } \\
\text { Method: Panel Least Squares } \\
\text { Date: 08/20/19 Time: } 16: 47 \\
\text { Sample: } 15 \\
\text { Periods included: } 5 \\
\text { Cross-sections included: } 14 \\
\text { Total panel (balanced) observations: } 70\end{array}$} \\
\hline Variable & Coefficient & Std. Error & t-Statistic & Prob. \\
\hline $\mathrm{C}$ & -0.141988 & 0.006360 & -22.32629 & 0.0000 \\
\hline LLERNER_INDEX & -0.002695 & 0.000155 & -17.35704 & 0.0000 \\
\hline LZSCORE & 0.003003 & 0.000672 & 4.468257 & 0.0000 \\
\hline LCAPITAL_ADEQUACY_TOTAL_CAPITAL & $\begin{array}{l}-0.004229 \\
\text { Effects Specification }\end{array}$ & 0.000342 & -12.38356 & 0.0000 \\
\hline \multicolumn{5}{|l|}{ Cross-section fixed (dummy variables) } \\
\hline R-squared & 0.972006 & Mean dependent var & & -0.194314 \\
\hline Adjusted R-squared & 0.963555 & S. D. dependent var & & 0.001247 \\
\hline Sum squared resid & $3.00 \mathrm{E}-06$ & Schwarz criterion & & -13.09412 \\
\hline Log likelihood & 494.4063 & Hannan-Quinn criter. & & -13.42328 \\
\hline F-statistic & 115.0174 & Durbin-Watson stat & & 4.235122 \\
\hline Prob (F-statistic) & 0.000000 & & & \\
\hline
\end{tabular}


Table 5 shows that capital adequacy ratio has positive effect, while both of cost efficiency and bank risk-taking have negative effect on market power that $\mathrm{R} 2=89.3 \%$, which is completely consistent with many literature researches such as the study [3, 19] and [25].

Table 5. The impact of cost efficiency, capital adequacy and risk-taking on market power.

\begin{tabular}{|c|c|c|c|c|}
\hline \multicolumn{5}{|l|}{$\begin{array}{l}\text { Dependent Variable: LLERNER_INDEX } \\
\text { Method: Panel Least Squares } \\
\text { Date: 08/20/19 Time: } 16: 49 \\
\text { Sample: } 15 \\
\text { Periods included: } 5 \\
\text { Cross-sections included: } 14 \\
\text { Total panel (balanced) observations: } 70\end{array}$} \\
\hline Variable & Coefficient & Std. Error & t-Statistic & Prob. \\
\hline $\mathrm{C}$ & -47.65676 & 2.533742 & -18.80885 & 0.0000 \\
\hline LCOST & -315.5415 & 18.17946 & -17.35704 & 0.0000 \\
\hline LZSCORE & 1.114487 & 0.222144 & 5.016948 & 0.0000 \\
\hline LCAPITAL_ADEQUACY_TOTAL_CAPITAL & $\begin{array}{l}-1.174154 \\
\text { Effects Specification }\end{array}$ & 0.164789 & -7.125196 & 0.0000 \\
\hline \multicolumn{5}{|l|}{ Cross-section fixed (dummy variables) } \\
\hline R-squared & 0.892750 & Mean dependent var & & -0.846667 \\
\hline Adjusted R-squared & 0.860372 & S. D. dependent var & & 0.218040 \\
\hline S. E. of regression & 0.081474 & Akaike info criterion & & -1.969545 \\
\hline Sum squared resid & 0.351818 & Schwarz criterion & & -1.423482 \\
\hline Log likelihood & 85.93407 & Hannan-Quinn criter. & & -1.752642 \\
\hline F-statistic & 27.57324 & Durbin-Watson stat & & 4.300800 \\
\hline Prob (F-statistic) & 0.000000 & & & \\
\hline
\end{tabular}

Table 6 shows that both market power and cost efficiency have a significant positive effect on bank-risk-taking that $\mathrm{R} 2=74.9 \%$. This is consistent with most of literature researches, while capital adequacy ratio has non-significant effect which contradicts with most of literature researches for the same reason mention above. (Analysis of table 2)

Table 6. The impact of cost efficiency, market power and capital adequacy on risk-taking.

\begin{tabular}{|c|c|c|c|c|}
\hline \multicolumn{5}{|l|}{$\begin{array}{l}\text { Dependent Variable: LZSCORE } \\
\text { Method: Panel Least Squares } \\
\text { Date: 08/20/19 Time: 16:51 } \\
\text { Sample: } 15 \\
\text { Periods included: } 5 \\
\text { Cross-sections included: } 14 \\
\text { Total panel (balanced) observations: } 70\end{array}$} \\
\hline Variable & Coefficient & Std. Error & t-Statistic & Prob. \\
\hline LCOST & 91.13208 & 20.39545 & 4.468257 & 0.0000 \\
\hline LLERNER_INDEX & 0.288912 & 0.057587 & 5.016948 & 0.0000 \\
\hline LCAPITAL_ADEQUACY_TOTAL_CAPITAL & $\begin{array}{l}0.091745 \\
\text { Effects Specification }\end{array}$ & 0.116722 & 0.786019 & 0.4354 \\
\hline \multicolumn{5}{|l|}{ Cross-section fixed (dummy variables) } \\
\hline R-squared & 0.749274 & Mean dependent var & & 2.338852 \\
\hline Adjusted R-squared & 0.673583 & S. D. dependent var & & 0.072607 \\
\hline Sum squared resid & 0.091203 & Schwarz criterion & & -2.773509 \\
\hline Log likelihood & 133.1850 & Hannan-Quinn criter. & & -3.102669 \\
\hline F-statistic & 9.899120 & Durbin-Watson stat & & 3.653800 \\
\hline Prob (F-statistic) & 0.000000 & & & \\
\hline
\end{tabular}

\section{Conclusion}

In this paper, it was tried to measure both of cost efficiency and market power; results show that Union National Bank Egypt and Export Development Bank have the highest cost efficiency, while, Societe Arabe International De Banque and National Bank of Kuwait Egypt have the lowest cost efficiency. However, Union National Bank Egypt and Egyptian Gulf Bank have the highest market power, while Suez Canal Bank and Qatar National Bank Alahly have the lowest market power. But also results addresses that there is no significant effort for enhancing neither cost efficiency nor market power which is addressed by low standard deviation ranges (0.043-0.155) and (0.03-0.35) respectively for all listed banks. 
As it could be seen from statistical regression analysis that capital adequacy ratio significantly responds positively to market power and negatively to cost efficiency, as such risk-taking significantly responds positively to both cost efficiency and market power, which is consistent with most of researches within literature review, while both capital adequacy ratio and risk-taking are not responding significantly to each other which contradict with most of researches within literature review and this may be addressed by some of activated acts of law 88 year 2003 that limit risk-taking for many risk types. However, cost efficiency significantly responds negatively to capital adequacy and positively to both market power and bank risk-taking, moreover market power significantly responds positively to capital adequacy and negatively to both cost efficiency and bank risk-taking, which is consistent with most of previous researches; All results addresses potential opportunities toward better performance in case of restructuring Egyptian bank law number 88 year 2003 to liberate decision making process especially for risk-taking and competition.

\section{References}

[1] Fiordelisi, F., Marques-Ibanez, D., \& Molyneux, P. (2011). Efficiency and risk in European banking. Journal of Banking and Finance, $35 \quad$ (5), 1315-1326. https://doi.org/10.1016/j.jbankfin.2010.10.005.

[2] Tan, Y., Floros, C., \& Anchor, J. (2017). The proftability of Chinese banks: Impacts of risk, competition and efficiency. Review of Accounting and Finance, 16 (1), 86-105. https://doi.org/10.1108/RAF-05-2015-0072.

[3] Fang, J., Lau, C. K. M., Lu, Z., Tan, Y., \& Zhang, H. (2019). Bank performance in China: A Perspective from Bank efficiency, risk-taking and market competition. Pacific Basin Finance Journal, 56, 290-309. https://doi.org/10.1016/j.pacfin.2019.06.011.

[4] Zhang, J., \& Jiang, H. (2018). Capital regulatory pressure, charter value and bank risk-taking: empirical evidence for China. Journal of Financial Regulation and Compliance, 26 (1), 170-185. https://doi.org/10.1108/JFRC-01-2017-0002.

[5] Sarkar, S., \& Sensarma, R. (2016). The relationship between competition and risk-taking behaviour of Indian banks. Journal of Financial Economic Policy, 8 (1), 95-119. https://doi.org/10.1108/JFEP-05-2015-0030.

[6] Raz, A. F. (2018). Risk and capital in Indonesian large banks. Journal of Financial Economic Policy, 10 (1), 165-184. https://doi.org/10.1108/JFEP-06-2017-0055.

[7] Sarkar, S., Sensarma, R., \& Sharma, D. (2019). The relationship between risk, capital and efficiency in Indian banking: Does ownership matter? Journal of Financial Economic Policy, $11 \quad$ (2), 218-231. https://doi.org/10.1108/JFEP-05-2018-0074.

[8] Nurboja, B., \& Košak, M. (2017). Banking efficiency in South East Europe: Evidence for financial crises and the gap between new EU members and candidate countries. Economic Systems,

41 , $122-138$. https://doi.org/10.1016/j.ecosys.2016.05.006.

[9] Doan, A. T., Lin, K. L., \& Doong, S. C. (2018). What drives bank efficiency? The interaction of bank income diversification and ownership. International Review of Economics and Finance, 55, 203-219. https://doi.org/10.1016/j.iref.2017.07.019.

[10] Koutsomanoli-Filippaki, A., Margaritis, D., \& Staikouras, C. (2009). Efficiency and productivity growth in the banking industry of Central and Eastern Europe. Journal of Banking and Finance, 33 (3), 557-567. https://doi.org/10.1016/j.jbankfin.2008.09.009.

[11] Hou, X., Wang, Q., \& Zhang, Q. (2014). Market structure, risk-taking, and the efficiency of Chinese commercial banks. Emerging Markets Review, 35 (2), 99-118. https://doi.org/10.1016/j.ememar.2014.06.001.

[12] Sarpong-Kumankoma, E., Abor, J., Aboagye, A. Q. Q., \& Amidu, M. (2017). Freedom, competition and bank efficiency in Sub-Saharan Africa. International Journal of Law and Management, $59 \quad$ (6), 1359-1380. https://doi.org/10.1108/ijlma-11-2016-0142.

[13] Zhu, N., Wu, Y., Wang, B., \& Yu, Z. (2019). Risk preference and efficiency in Chinese banking. China Economic Review, 53, 324-341. https://doi.org/10.1016/j.chieco.2018.11.001.

[14] Efthyvoulou, G., \& Yildirim, C. (2014). Market power in CEE banking sectors and the impact of the global financial crisis. Journal of Banking and Finance, 40, 11-27. https://doi.org/10.1016/j.jbankfin.2013.11.010.

[15] Hsiao, C., Shen, Y., \& Bian, W. (2015). Evaluating the effectiveness of China's financial reform-The efficiency of China's domestic banks. China Economic Review, 35, 70-82. https://doi.org/10.1016/j.chieco.2015.05.006.

[16] Khan, H. H., Kutan, A. M., Naz, I., \& Qureshi, F. (2017). Efficiency, growth and market power in the banking industry: New approach to efficient structure hypothesis. North American Journal of Economics and Finance, 42, 531-545. https://doi.org/10.1016/j.najef.2017.08.004.

[17] Fernandez, Ana I. Gonzalez, Francisco, Suarez, Nuria (2013). How do bank competition, regulation, and institutions shape the real effect of banking crises? International evidence, Journal of International Money and Finance, 33, 19-40. https://doi.org/10.1016/j.jimonfin.2012.10.002.

[18] Abou-El-Sood, H. (2017). Corporate governance structure and capital adequacy: implications to bank risk-taking. International Journal of Managerial Finance, 13 (2), 165-185. https://doi.org/10.1108/IJMF-04-2016-0078.

[19] Lapteacru, I. (2017). Market power and risk of Central and Eastern European banks: Does more powerful mean safer? $\begin{array}{lll}\text { Economic } & \text { Modelling, } & 63,\end{array}$ https://doi.org/10.1016/j.econmod.2017.01.022.

[20] Bitar, M., Pukthuanthong, K., \& Walker, T. (2018). The effect of capital ratios on the risk, efficiency and profitability of banks: Evidence from OECD countries. Journal of International Financial Markets, Institutions and Money, 53, 227-262. https://doi.org/10.1016/j.intfin.2017.12.002.

[21] Berger, A. N., Klapper, L. F., \& Turk-Ariss, R. (2009). Bank competition and financial stability. Journal of Financial Services Research, 35 (2), 99-118. https://doi.org/10.1007/s10693-008-0050-7. 
114 Aly Saad Mohamed Dawood: Cost Efficiency, Market Power, Solvency Risk, and Capital Adequacy for Listed Banks in Egypt

[22] Houston, J. F., Lin, C., Lin, P., \& Ma, Y. (2010). Creditor rights, information sharing, and bank risk-taking. Journal of Financial Economics, 96, 485-512. https://doi.org/10.1016/j.jfineco.2010.02.008.

[23] Nguyen, T. (2013). The disciplinary effect of subordinated debt on bank risk-taking. Journal of Empirical Finance, 23, 117-141. https://doi.org/10.1016/j.jempfin.2013.05.005.
[24] Tan, Y., \& Floros, C. (2013). Risk, capital and efficiency in Chinese banking. Journal of International Financial Markets, Institutions and Money, 26, 378-393. https://doi.org/10.1016/j.intfin.2013.07.009.

[25] Tan, Y., \& Floros, C. (2018). Risk, competition and efficiency in banking: Evidence from China. Global Finance Journal, 35, 223-236. https://doi.org/10.1016/j.gfj.2017.12.001. 